\title{
橋梁振動の人間工学的評価法 ERGONOMIC EVALUATION METHODS FOR BRIDGE VIBRATIONS
}

\section{1. まえがき}

土木構造物は動的外力を受けて, 大きいか小さいかの 差こそあれ振動する。このことから従来より振動につい ての多くの研究がなされてきた。それらの研究は, 主と して外力が作用したとき構造物がどのような動的応答を 示すかについての力学的研究や構造物が振動することに よってどのような影響(たとえば, 疲労や塑性変形など) を受けるかについての材料強度学的研究であった。

ところが, 構造物の振動が構造物 以外に及ぼす影響 (たとえば，人間への影響など）はほとんど考慮されて いないのが現状である。

橋梁の振動においても同様で, 最近, よく振動する橋 梁が現われるようになり多くの実験が行われ, 動的安定 性の検討がなされてきた。しかし, その検討は主として 力学的あるいは材料強度学的に行われてきた。ところ が, “橋梁の振動が大きい”ことにより歩行者から次の ような反応があるであろう。

(1) 振動で橋梁は壊れるのではないかといら不安。

（2）こんなに摇れるのは設計上あるいは施工上の欠 陥があるのではないかといら非難。

（3）振動による生理的影響の結果として歩けなくな るという不満。

以上の 3 点のうち, (3) の生理的影響が生ずるほどの 振動は許されないとしても，(1)，(2) は主観的反応であ るために動的安定性の検討がなされ，「橋は摇れるもの であり，大丈夫だ」と歩行者に教育すれば，かなり大き な振動にも耐えられる，との報告”もある。しかし，橋 梁の振動はなるべく小さいほうが望ましく, 設計の段階 に拉いて橋梁の振動をより小さくする努力は払うべきで

\footnotetext{
* 正会員 工博 金沢大学教授 工学部土木工学科

** 正会員金沢大学助手 工学部土木工学科 (垷在福井工業大学講師)
}

小堀 為 雄* - 梶 川康 男** By Tameo Kobori and Yasuo Kajikawa

あると考える。

そこで, 本論文では振動が人間に及ぼす影響を, 生理 的影響・人体の動的応答 - 心理的反応に大別し, それぞ れについて考えてみた。まず, 生理的影響についての研 究は主に医学の分野で行われているので, その成果を基 に橋梁の振動に挨いてどの程度の影響があるかを考え た。次に, 人体の動的応答については橋梁の振動におい てこの種の問題をいかに考慮すべきかについて, 実験を 含めて考察した。最後の問題である心理的反応について は従来, 乗心地や居住の快適性などにおいて研究され, また, 最近計量心理学の手法が発展し, 振動に対しても

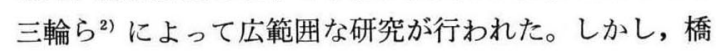
梁の振動を対象に行われた研究は非常に少ない。その理 由の 1 つに, 従来の研究成果からこの問題を考えるため には姿勢や振動波形の点で未解決な問題が残されている ためであろう。橋梁における振動感をより小さくするよ うな橋梁構造や防振方法を考えるためには, この基本的 な問題が解決されねばならない。その第一段階として, 弛緩した直立姿勢において基礎的な振動感覚実験を行 い, 実橋振動の実態調查結果をあわせてすでに文献) で

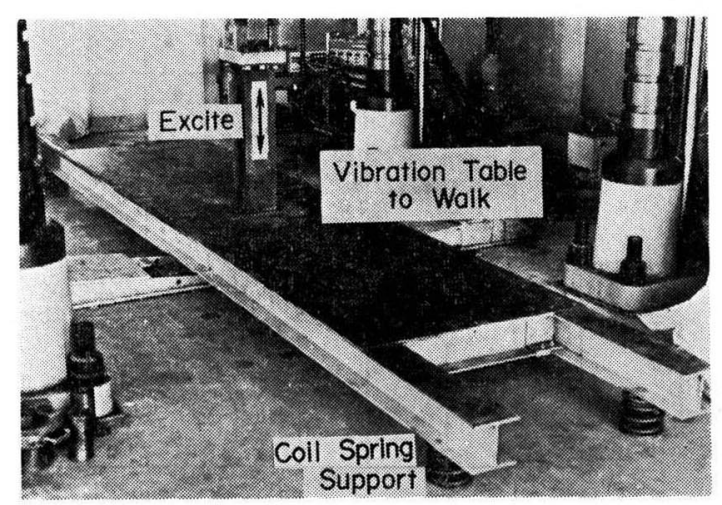

4 点弾性支持, 幅 $1.2 \mathrm{~m}$, 長さ $6.5 \mathrm{~m}$ 動力源 島津サーボパルサ EHF-40 図一1 振 動 台 
報告した。ところが，文献 3)でも指摘したように橋梁上 で振動を受ける場合，ほとんどの人が歩いていることや 橋梁振動は隣接した優勢な低周波成分を数個もつ不規則 な振動であることを考慮せねばならない。そこで，本論 文においては, 図一1 に示すような歩行が可能な大型振 動台を製作し，この上を実際に歩いたとき，どのように 振動を感ずるかを測定し，歩行時における振動の心理尺 度を求めた。また，実波形あるいはそれに近い波形を用 いて, ランダムな振動に対する感覚実験をも実施し, 橋 梁上での実感にできるだけ近い評価尺度を求めるととも に，道路橋に扝ける振動恕限度を提案した。

\section{2. 生理的影響}

まず，最初に，振動を受けることにより生理上どのよ うな変化が生ずるかを考えた。人間が振動を受ける際， 局所的に受ける場合と全身に受ける場合がある。前者は 振動工具などを使うとき問題になりレイノー現象などと して，その影響はよく知られている。後者は乗心地や居 住性などを問題にする場合であり，橋梁の振動もこれに 属する。全身振動を受けたとき, 人体は安定した状態を 保持するために交感神経の機能が昂進し，その結果とし て循環器・呼吸器・消化器などにさまざまな反応が生ず る。また，尿中成分やホルモンの変化といら内分泌系の 反応・せき柱の異常, 聴器や音声に及ぼす影響などが現 われるといわれている4) 。

これらの影響を総括して岡田 ${ }^{6}$ は 図一2 のようにまと め, 加速度 $0.08 \mathrm{~g}$ 以下での生理機能障害は報告されて おらず，これ以下の振動強度についての実験が必要なこ とを強調している。

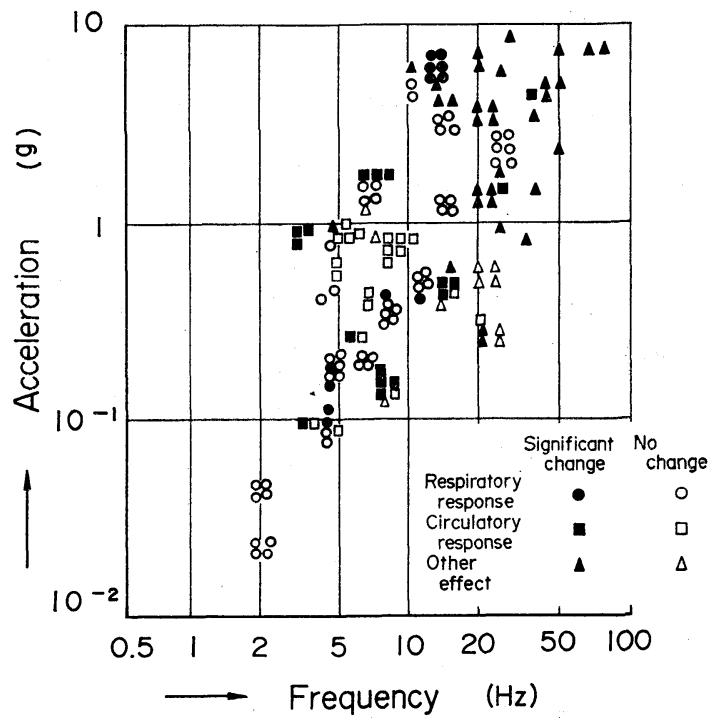

図一2 全身振動の人体機能に及ぼす影響6)
以上のことより，橋梁の振動数がほとんど $5 \mathrm{~Hz}$ 以下 であり, 加速度も通常ではそれほど大きくならないこと を考えれば,この生理的影響は小さいものと考えられ る。しかし，現実に「めまい」を生ずるような橋梁が存 在することは周知のとおりである。これは, 従来の生理 的影響に関する研究が大きな振動を対象にしてきたこと もあり, 今後小さな振動での研究が待たれているのが現 状である。

\section{3. 人体の動的応答}

この種の研究は，人体の共振点などを知る上で重要で あるとともに振動が人体各部へどの程度伝達されるかを 知ることもできる。これにより振動を受ける人間の安全 性を高めるために非常に役立っている。この応答は，人 間の姿勢や振動の方向によって大きく左右される。そこ で，橋梁の振動を対象にしていることから立位における 上下方向の振動について考えてみた。

Dieckmann や Radke ${ }^{4}$ によれば，振動台と人体各部 との伝達率 (加速度比) は図一3 の実線のように示され ている。著者らも，図一1 に示した振動台を用い，この 振動台と被験者に小型加速度計を取りつけて同様な伝達 率を求めてみた。その結果を図一3 の破線で示した。図 一3 の両者を比較してみるとほぼ同じ傾向にある。立位 では頭部( ・臀部囘ともに $3 \sim 6 \mathrm{~Hz}$ に共振点がある。ま た，図中(C)の線で示した膝を曲げた状態は橋梁上を歩く 姿勢に類似している。この状態に扔いて共振点がはっき りとは認められず, $3 \mathrm{~Hz}$ 以上の振動で伝達率は小さく

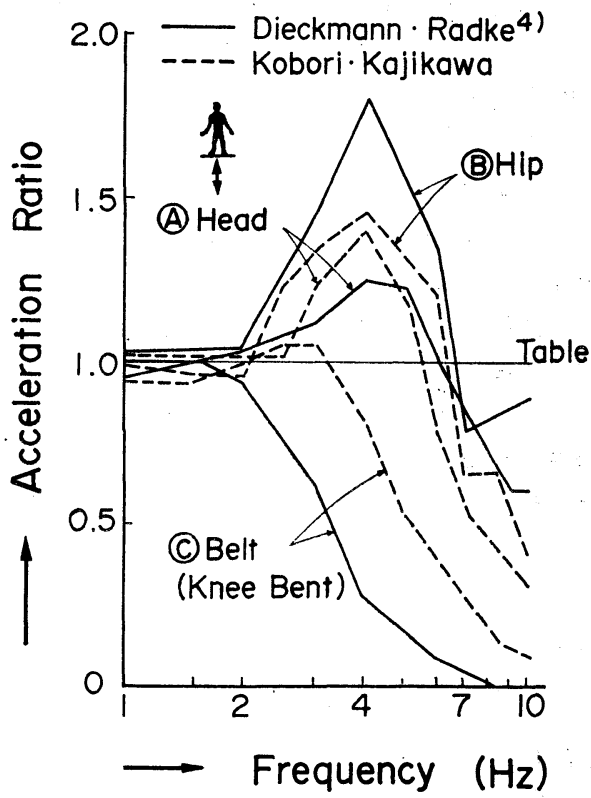

図-3 人体の伝達率 
なっている。これと同じ傾向は岡田の研究8) によっても 認められている。このことは，歩いているときに高い振 動数の振動が上体には伝達されずに，振動感が足に集中 していることと一致する。

以上のことより橋梁上で歩行者が常に歩いているなら ば，この種の影響はないといえるが，立ち止まることの 多い場合には $3 \sim 6 \mathrm{~Hz}$ の振動は好ましくない。これに ついては, 次節で述べる心理的反忘とともに考える必要 がある。

\section{4. 心理的反応}

\section{（1）評価 尺度}

近年, 心理学の分野において計量化の手法が多く用い られるよらになった。特に，音響関係では音響心理学と よばれる手法で多くの研究がなされ, Phon や Sone な ど多くの尺度が提案されている。また，振動関係では三 輪ら 2) が音響心理学の手法を用いて, 明確な結果をわれ われに与えてくれた。ところが，三輪らの研究を含めて 従来の評価尺度は座位または緊張した立位に対して適用 できるが，橋梁上の歩行者に対して適用するには姿勢の 点に疑問がある。この疑問を解決するには，弛緩した立 位や実際に歩いている姿勢（以後, 歩行位という) での 実験が必要である。そこで，これらの姿勢における評価 尺度を検討するために計量心理学的手法の 1 つであるマ グニチュード推定法 ${ }^{3), 9) ~(M a g n i t u d e ~ e s t i m a t i o n ~ m e-~}$ thod) を用いた。この方法は, 標準の振動 $(3 \mathrm{~Hz}$, 振幅 $1 \mathrm{~mm}$ ) を設定し，その振動によって与えられる感覚の 大きさをかりに 10 として,さまざまな振動 $(1 \sim 10 \mathrm{~Hz}$, 振幅 $0.1 \sim 5 \mathrm{~mm}$ の組合せ 80 点）が与える感覚の大き さがいくつに相当するかを数值によって答えさせるもの である。この手法による驰緩した立位の結果については すでに報告 ${ }^{3}$ した。ところが，橋梁上では通常歩行位で あることから，図一1 に示した振動台の上を 1 人ないし 2 人の被験者が歩いたとき，振動をどのように感ずるか を同様にこの手法を用いて実験を行った。図一4 は被験 者 11 人に対し 2 回ずつ計 22 回の実験結果を各点の振動 ごとに対数平均した值を示したものである。図中, 斜め に引いた細線はマグニチュード等值線すなわち等感覚線 の一例である。これより振動数と変位振幅はマグニチュ ードをパラメーターに指数関係にあることがわかる。そ こで, 等しい感覚を生じさせている振動の刺激を次式で 定義する ${ }^{3)}$ 。

$$
S=a \omega^{m}
$$

ここに, $S:$ 振動感覚を生ずるための刺激 $a:$ 変位振幅 $(\mathrm{cm})$

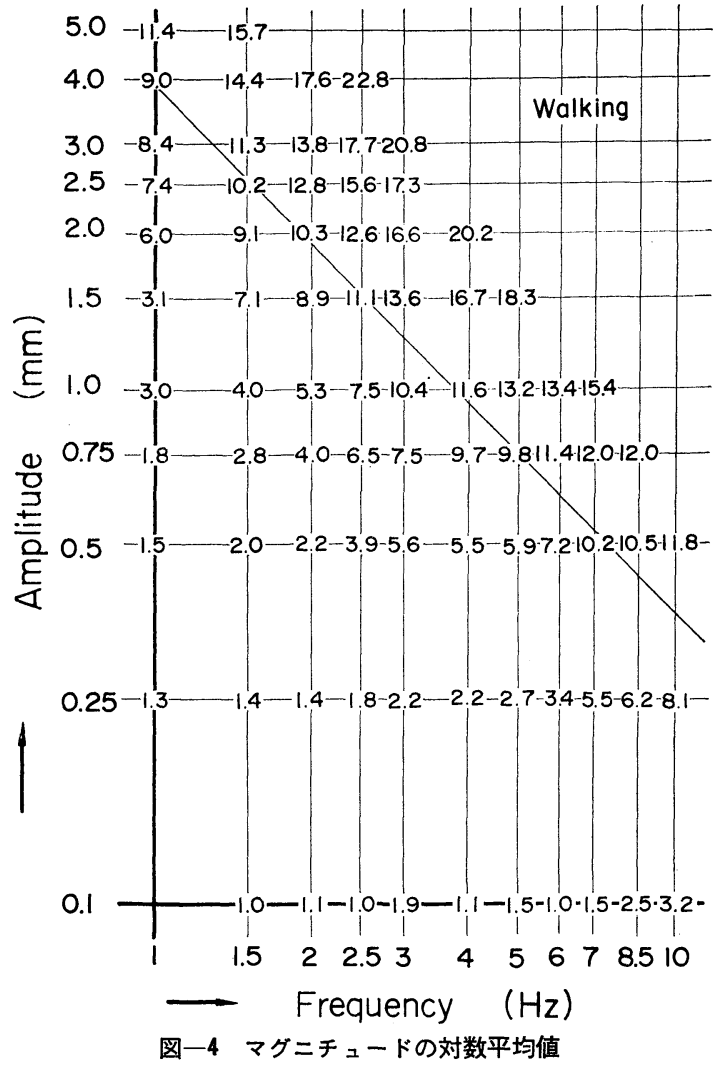

$\omega:$ 円振動数 $(\mathrm{rad} / \mathrm{sec})$

$m: \omega$ に関する指数

式（1）の両辺を対数にとると式（2）のように変形され る。

$$
\log _{10} a=\log _{10} S-m \log _{10} \omega
$$

したがって，マグニチュード等值線の勾配は，等しい 感覚を生じさせている刺激に振動数がどの程度関係する かを示す指数 $m$ を表わしている。そこで，マグニチュ 一ドと振動数・变位振幅との重回帰を求めると, 歩行位 においては等值線の勾配はほぼー1になる。これは, 刺 激として振動速度を考えるのが適切であることを示して いる。弛緩した立位においては，この勾配がほぼ -1.4 であった。歩行位に扮いてこの勾配が緩くなることは， 前節で示したように歩行位において高い振動数の振動が 脚部に吸収されてしまうことから考えれば理解される。

次に, 刺激として定義された量（歩行位の場合には振 動速度 $a \omega$, 弛緩した立位の場合には $\left.a \omega^{1.4}\right)$ とマグニチ ニードがどのような関倸にあるかを調べた。図一5(a)に は, 振動速度とマグニチュードを対数で示した。マグニ チュードの小さい範囲ではばらつきが大きいが両者は破 線で示したようにほぼ曲線関係にある。そこで, この曲 線を 2 本の直線で近似することにする。この両対数軸上 で直線関倸にあることは次式で示す Stevens $の ~ n$ 乗法 


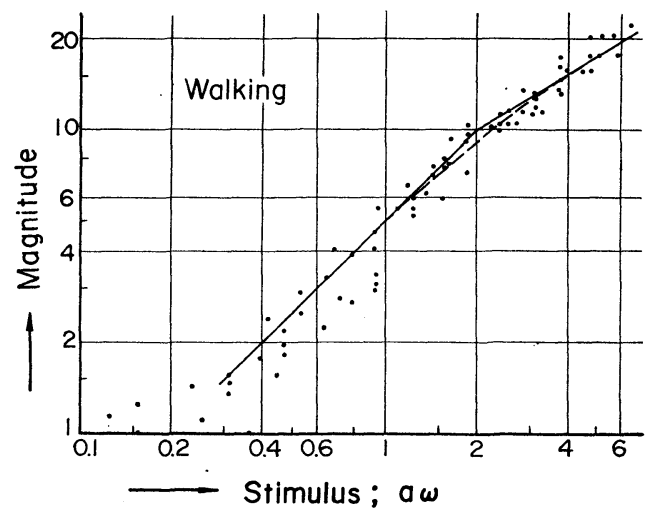

図一5(a) 歩行位における刺激とマグニチュード

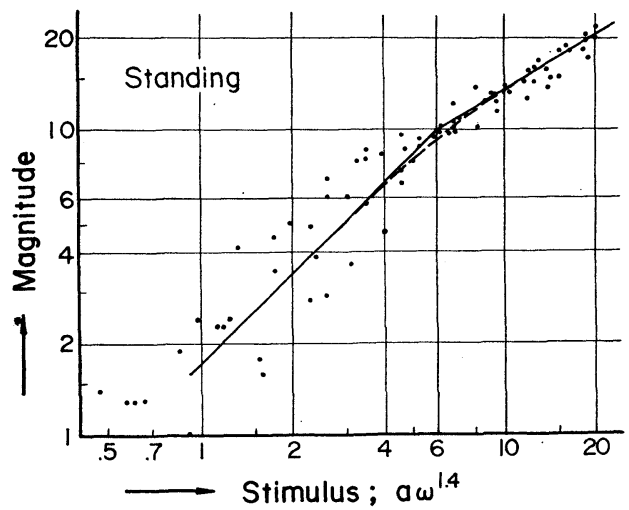

図一5(b) 立位における刺激とマグニチュード

則 $^{32,9)}$ が成り立つことを示している。

$R=k S^{n}$

ここに, $R$ : 感覚の相対的な大きさ（比率尺度值）

$S:$ 振動刺激

$n:$ 様相特性指数

$k:$ 基準值などに関する定数

ここで，われわれの測定したマグニチュードは基準量に 対する感覚量の比を表わしていることから, 式 (3) の $R$ と同意であると考えることができる。したがって，式

(3) の両辺の対数を考えれば，次のようになる。

$$
\log _{10} R=\log _{10} k+n \log _{10} S
$$

ここで, 様相特性指数 $n$ は図一5 の直線の勾配を示し ており, 図一5(a) すなわち歩行位の場合は次 の值となる。

$$
\begin{aligned}
& S(=a \omega) \leqq 2 \mathrm{~cm} / \mathrm{sec} \text { では } n \fallingdotseq 1.0 \\
& S(=a \omega)>2 \mathrm{~cm} / \mathrm{sec} \text { では } n \fallingdotseq 0.6
\end{aligned}
$$

$k$ は前述のように基準值などに関する定数であ るので, 識閾に関する項 $S_{0}{ }^{n}$ をも含めて考える と

$$
\log _{10} R=n \log _{10}\left(S / S_{0}\right)-b
$$

ここで, $b=-\log _{10}\left(k S_{0}{ }^{n}\right)$ である。
式 (5) を三輪ら 2$)$ の提案する記号を用いて表現すると 次のようになる。 $R$ を振動の大きさ $V G$ (Vibration Greatness の略) に, $n$ を $20 N$ とし, $20 \log _{10}\left(S / S_{0}\right)$ で表わされる量を振動の大きさのレベル VGL (Vibration Greatness Level の略) に置き換えれば,

$$
\log _{10} V G=N(V G L-B)
$$

となる。ここで, $B$ は $V G$ 值の基準を $V G L$ のどこに 置くかによる任意な定数である。

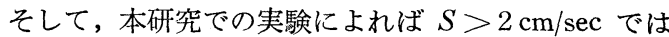
$n$ が約 0.6 であるので $N$ は 0.03 となり, 三輪ら ${ }^{2)}$ の評 価尺度や音の大きさを示す尺度 “Sone”, とほぼ一致す る。

以上に述べたのは歩行位についてであるが，弛緩した 立位の場合には刺激 $S$ として $a \omega^{1.4}$ を考えて, マグニ チュードと刺激の関係 ${ }^{3)}$ を図一5(b)に示した。この図よ り直線の勾配は次の值となる。

$$
\begin{aligned}
& S\left(=a \omega^{1.4}\right) \leqq 6 \text { では } n \fallingdotseq 1.0 \\
& S\left(=a \omega^{1.4}\right)>6 \text { では } n \fallingdotseq 0.6
\end{aligned}
$$

これより, 立位の場合にも刺激 $S$ として考える量を変 えれば, 式 (6) で同様に振動の大きさ $V G$ が得られる。

以上に述べてきた尺度は，マグニチュード推定法に基 ゔくもので，刺激がある值以上であれば三輪ら²) VG やSteveus の Sone ${ }^{10)}$ と一致し，興味ある結果である が，刺激の小さい範囲では $n$ が 1.0 となり，刺激と感覚 の大きさが比例関係にある。そこで，この範囲での尺度 を照査するために，分・倍数刺激選択法 ${ }^{9}$ (Fractionation and Multiple stimuli method) とよばれる計量 心理学の手法に基づく実験を行った。

この方法は，標準刺激を選んでおき主観的意味でその $1 / 2$ あるいは 2 倍に相当する刺激を用意した刺激群の中 から選択するものである。そこで, 本研究では表一1に 示したような 4 点の標準振動を決め, その振動と同じ振

\begin{tabular}{|c|c|c|c|c|c|c|c|c|}
\hline \multirow{3}{*}{ Case } & \multirow{3}{*}{$\begin{array}{l}\text { Test } \\
\text { Freq. } \\
(\mathrm{Hz})\end{array}$} & \multirow{3}{*}{$\begin{array}{c}\text { Standard } \\
\text { Ampl. } \\
(\mathrm{mm})\end{array}$} & \multicolumn{4}{|c|}{ Produced Ampl. Range(mm) } & \multirow{2}{*}{\multicolumn{2}{|c|}{$\underset{(\mathrm{mm})}{\text { Mean Ampl. }}$}} \\
\hline & & & \multicolumn{2}{|c|}{ Fract.* } & \multicolumn{2}{|c|}{ Mult.** } & & \\
\hline & & & Lower & Upper & Lower & Upper & Fract.* & Mult.** \\
\hline A & 1.5 & 1.00 & 0.25 & 0.70 & 1.25 & 3.50 & 0.50 & 2.18 \\
\hline B & 2 & 0.75 & 0.20 & 0.65 & 0.80 & 2.60 & 0.40 & 1.58 \\
\hline C & 3 & 0.33 & 0.13 & 0.24 & 0.44 & 1.22 & 0.17 & 0.73 \\
\hline D & 4 & 0.17 & 0.068 & 0.154 & 0.205 & 0.684 & 0.10 & 0.33 \\
\hline
\end{tabular}
動数で小さい振幅の振動を 10 点, 大きい振幅の振動を 10 点，それぞれ等差数列的に用意した。それらの上・ 下限の振幅を表一1 に示した。予備実験として 3 人の被 験者に対し弛緩した立位・歩行位の両姿勢において行っ たが，それぞれには有意な差は認められなかったので，

\section{表一1 分・倍数刺激選択法}

* Fract. は分数刺激選抧法 (Fractionation method の略)

** Mult. は倍数刺激選択法 (Multiple method の略) 


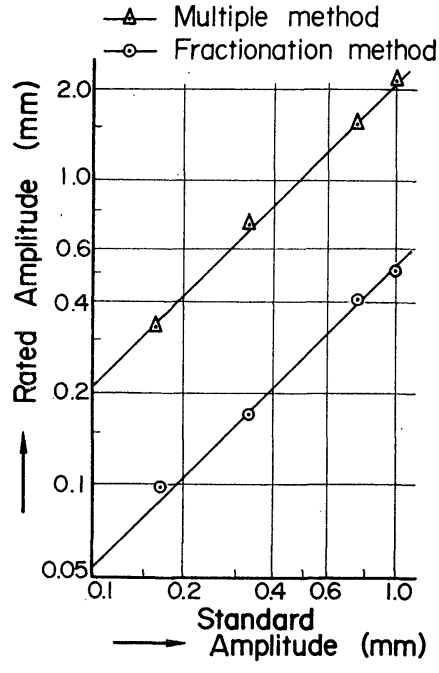

図一6 基準振幅と評定振幅

弛緩した立位で 11 人の被験者に対し各 2 回ずつ計 22 回 行った。それらの結果を対数平均した值を表一1 に示し た。刺激と感覚の大きさとの関係が式 (3) で表わされる ようにべき乗であるとすれば, 標準振動の刺激 $\left(S_{1}\right)$ と 選択された分・倍数刺激 $(S)$ との関係は次式となる。

$$
\frac{R}{R_{1}}=\frac{k S^{n}}{k S_{1}{ }^{n}}=\left(\frac{a}{a_{1}}\right)^{n}=\beta^{r}
$$

ここで, $\beta$ は公称比 2.0 であり, $\gamma$ は分数・倍数によ って -1 , +1 をとる。

式 (7) の両辺の対数をとり変形すれば

$$
\log _{10} a=\log _{10} a_{1}+r \frac{\log _{10} \beta}{n}
$$

となる。図一6に測定結果をプロットした。各点を結ぶ 直線上の任意な点より $n$ を求めるとほぼ 1.0 になり, マ グニチュード推定法によって得られた指数 $n$ が妥当なも のであることが確認できた。この指数 $n$ がほぼ 1.0 にな ることは，音の大きさを示す “Sone” の指数において も認められる。すなわち, 40 Phon 以上では音の大きさ が音圧の 0.6 乗に比例しているが，20４0 Phon では音 圧にほぼ比例しているといえる ${ }^{10)}$ 。これは本研究で求め た指数と全く一致し，音の大きさと同様に式 (6)によっ て振動の心理的大きさを評価することができる。

\section{（2）ランダム振動に対する検討}

（1）において，橋梁振動の評価をする際には歩行者の 姿勢によって大きく変わることを示し，歩行位における 評価尺度について述べた。橋梁振動のも5 1 つの特徴と して, 振幅が規則正しい正弦振動ではなく不規則なラン ダム振動であることがあげられる。この振動に対しての 心理的反応を検討するために, 一対比較法により次のよ うな実験を行った。 a) ランダム振動等価法

この方法は, 実橋の振動波形を再生して振動台を制御 し，その感覚に等しい正弦振動を見つけ出すものであ る。まず, 表一2 のように実橋の変位記録から数種の波 形 $(\mathrm{A} \sim \mathrm{F})$ を選び，その卓越振動数 $(f)$ と変位振幅の 標準偏差 $\left(\sigma_{r}\right)$ をスペクトル解析により求めた。そして, その波形の卓越振動数と等しい振動数で振幅が $\sigma_{r}$ から $3 \sigma_{r}$ まで $0.1 \sigma_{r}$ 刻みの 21 点の正弦振動を用意し, 実 波形による再生振動と正弦振動とを交互に提示し感覚的 等価点を求めた。予備実験として 3 人の被験者に対し弛 緩した立位・歩行位の両姿勢において行ったが，それぞ れには有意な差は認められなかったので弛緩した立位で 11 人の被験者に対し各 2 回ずつ計 22 回行った。また, 各ケースにおいて再現性を確かめるために，同じ波形を 用い増幅率を変化させて行った。その結果，得られた等 価振幅の対数平均值を表一 2 に $A_{s}$ として示し,さら に, この $A_{s}$ とランダム振動の標準偏差 $\sigma_{r}$ との比を示 した。

この実験結果より，一部のケースを除いてランダム振 動の標準偏差のほぼ 1.4 倍の振幅をピークにもつ正弦振 動と感覚的には等しいことがわかる。このことは，橋梁 の振動波形は一見ランダムなように見えるが，決してそ のランダム性は強いものではなく, 橋梁の振動による心 理的反忘を考える上では正弦振動によって得られた評価 尺度・恕限度がそのまま適用できることを示している。

b) 複合正弦振動等価法

実橋の振動には数個の優勢な周波数成分が同時に含ま れていることが多い。このような場合，それぞれの振動 刺激を考え，その和を評価すると，それらが同時に生ず ることがまれなため過大評価となる。そこで，それぞれ の成分をどのように評価すべきであるかを検討しなけれ ばならない。騒音関係では Stevens の荷重加算法 ${ }^{10)}$ が 用いられ，また，三輪ら ${ }^{2)}$ は振動においてもこの加算法

\begin{tabular}{|c|c|c|c|c|}
\hline \multirow{2}{*}{ Case } & \multicolumn{2}{|c|}{ Random Vibration } & \multirow{2}{*}{$\begin{array}{l}\text { Sinusoidal } \\
\text { Ampl. } A_{s}\end{array}$} & \multirow{2}{*}{$\frac{A_{s}}{\sigma_{r}}$} \\
\hline & Freq. ( $\mathrm{Hz})$ & $\sigma_{r}{ }^{*}(\mathrm{~mm})$ & & \\
\hline \multirow{2}{*}{ A } & \multirow{2}{*}{2.01} & 0.95 & 1.59 & 1.67 \\
\hline & & 1.27 & 2.18 & 1.72 \\
\hline \multirow{2}{*}{ B } & \multirow{2}{*}{2.47} & 0.84 & 1.17 & 1.39 \\
\hline & & 1.66 & 2.32 & 1.40 \\
\hline \multirow{2}{*}{$\mathrm{C}$} & \multirow{2}{*}{2.48} & 1.37 & 2.06 & 1.50 \\
\hline & & 1.78 & 2.63 & 1.48 \\
\hline \multirow{2}{*}{ D } & \multirow{2}{*}{2.74} & 1.10 & 1.52 & 1.38 \\
\hline & & 1.46 & 2.05 & 1.40 \\
\hline \multirow{2}{*}{$\mathrm{E}$} & \multirow{2}{*}{3.39} & 0.53 & 0.71 & 1.34 \\
\hline & & 0.82 & 1.11 & 1.35 \\
\hline \multirow{2}{*}{$\mathrm{F}$} & \multirow{2}{*}{4.11} & 0.78 & 1.13 & 1.45 \\
\hline & & 1.17 & 1.80 & 1.54 \\
\hline
\end{tabular}

表一2 ランダム振動等価法

*この $\sigma_{r}$ は実効振幅 (RMS 值) である. 
表一3 複合正弦振動等価法

\begin{tabular}{|c|c|c|c|c|c|c|c|c|c|c|c|}
\hline \multirow{3}{*}{ Case } & \multicolumn{2}{|c|}{ Main Vibration } & \multicolumn{2}{|c|}{ Added Vibration } & \multicolumn{7}{|c|}{ Equivalent Vibration } \\
\hline & \multirow{2}{*}{$f(H z)$} & \multirow{2}{*}{$a(\mathrm{~mm})$} & \multirow{2}{*}{$f(\mathrm{~Hz})$} & \multirow{2}{*}{$a(\mathrm{~mm})$} & \multirow{2}{*}{$f(\mathrm{~Hz})$} & \multicolumn{3}{|c|}{ On Standing Posture } & \multicolumn{3}{|c|}{ On Walking Posture } \\
\hline & & & & & & $A_{s}(\mathrm{~mm})$ & $S_{s}$ & $\left(\sum S^{2}\right)^{1 / 2}$ & $A_{w}(\mathrm{~mm})$ & $S_{w}$ & $\left(\sum S^{2}\right)^{1 / 2}$ \\
\hline A & 1.5 & 1.43 & 3.0 & 0.62 & 1.5 & 2.12 & 4.90 & 5.02 & 2.01 & 1.89 & 1.78 \\
\hline B & \multirow{6}{*}{2.0} & \multirow{6}{*}{1.04} & 1.5 & 1.43 & \multirow{6}{*}{2.0} & 1.43 & 4.95 & 4.89 & 1.56 & 1.96 & 1.88 \\
\hline $\mathrm{C}$ & & & 3.0 & 0.62 & & 1.51 & 5.22 & 5.22 & 1.48 & 1.86 & 1.75 \\
\hline $\mathrm{D}$ & & & 4.0 & 0.60 & & 1.78 & 6.16 & 6.55 & 1.55 & 1.95 & 1.99 \\
\hline $\mathrm{E}$ & & & 1.5 & 0.66 & & 1.39 & 4.81 & 3.91 & 1.30 & 1.63 & 1.45 \\
\hline $\mathrm{F}$ & & & 3.0 & 0.30 & & 1.36 & 4.70 & 4.04 & 1.26 & 1.58 & 1.43 \\
\hline G & & & 4.0 & 0.22 & & 1.32 & 4.56 & 4.12 & 1.25 & 1.57 & 1.42 \\
\hline $\mathrm{H}$ & \multirow{3}{*}{3.0} & \multirow{3}{*}{0.62} & 1.5 & 0.66 & \multirow{3}{*}{3.0} & 0.72 & 4.39 & 4.08 & 0.70 & 1.32 & 1.32 \\
\hline I & & & 2.0 & 0.45 & & 0.71 & 4.33 & 4.09 & 0.68 & 1.28 & 1.29 \\
\hline$J$ & & & 4.0 & 0.22 & & 0.69 & 4.21 & 4.28 & 0.68 & 1.28 & 1.28 \\
\hline
\end{tabular}

が成り立つとしている。

そこで, 本研究に㧤いては橋梁の振動数範囲を考慮し

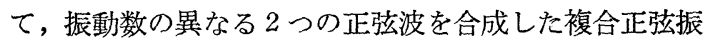
動に対する感覚と等しい大きさの感覚を与える単正弦振 動を見つけ出す実験を行った。単正弦波の振幅は複合正 弦波の成分の 1 つと同じ振幅から 0.1 倍刻みで 3 倍まで 21 点の振動を用意し, 合成振動・単正弦振動の順に交 互に提示し感覚的等価点を求めた。用意した複合正弦波 の振動数・振幅と等価させた単正弦波の振動数を表一-3 に示した。この実験においては姿勢により異なった結果 が予想されたので驰緩した立位・歩行位の両姿勢でそれ ぞれ 11 人の被験者に対し各 2 回ずつ計 22 回行った。そ れらの結果を対数平均した振幅を表一 3 の $A_{s}, A_{w}$ の欄 に示した。これらの結果において荷重加算法が成り立つ とはいえない。ところが, 実際には振動が合成されたも のであるために，その刺激の大きさはそれぞれの二乗和 の平方根と考え，等価である正弦振動の刺激と比較する と表一3 に示したように類似した值となる。これは次の ことを示している。すなわち，振動の刺激として考えら れる量の二乗和の平方根を求めれば，その振動に対する 心理的大きさを求めることができる。

\section{（3）振動恕限度の検討}

(1)，(2) では，橋梁の振動が人間に及ぼす心理的反応 の評価尺度を検討するための計量化に関する実験，およ びランダム振動に対する実験の結果から，評価尺度が構 成されることを述べた。振動による心理的反応におい てもら1つ重要なことに振動の大きさによってどのよ うな感じを持っかがある。これを調べるために用いられ る1つの心理学的手法には通常, 系列カテゴリ法31,99 (Method of successive categories) とよばれる一種の アンケート調查がある。この手法は, 前もって数段階の カテゴリを用意し，種々の振幅と振動数とを組合せた振 動を受けたとき, 被験者がどのカテゴリに属する感じを

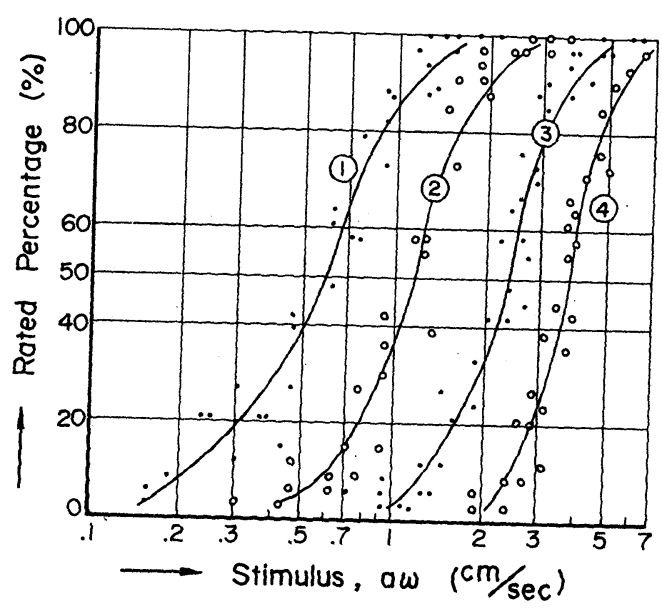

图一7 各カテゴリの刺激量と評定率

(○の中の数字はカテゴリ番号を示す)

持つかを調べるものである。

この調査のうち，弛緩した立位における結果はすでに 報告)した。今回は特に歩行位においてどのような感じ を持つかについて調查した。立位では“不快”を主に考 えたのに対し，歩行位では“歩きにくい”といらカテゴ リを主に考え，表一4のようなカテゴリを用意した。実 験は 11 人の被験者に対し各 3 回ずつ計 33 回の測定を行 い，その結果を次のように整理した。まず，(1)に示し た尺度により歩行位の場合には振動の刺激として振動速

表-4 歩行時のカテゴリと闘値

\begin{tabular}{|c|c|c|c|c|}
\hline \multirow{2}{*}{$\begin{array}{l}\text { Category } \\
\text { No. }\end{array}$} & \multirow{2}{*}{ Content of Category } & \multicolumn{3}{|c|}{ Lower limit $(\mathrm{cm} / \mathrm{sec})$} \\
\hline & & Peak & Value & RMS Value \\
\hline 0 & 全く感じない(Not perceptible) & & - & - \\
\hline 1 & 少し感じた (Lightly perceptible) & & 0.6 & 0.42 \\
\hline 2 & $\begin{aligned} \text { 明らかに感した } \\
\text { (Definitely perceptible) }\end{aligned}$ & & 1.2 & 0.85 \\
\hline 3 & $\begin{array}{l}\text { 少し歩きにくい (Lightly hard to walk) } \\
\text { (Ligh }\end{array}$ & & 2.4 & 1.7 \\
\hline 4 & $\begin{array}{l}\text { 大いに歩きにくい } \\
\text { (Extremely hard to walk) }\end{array}$ & & 3.8 & 2.7 \\
\hline
\end{tabular}




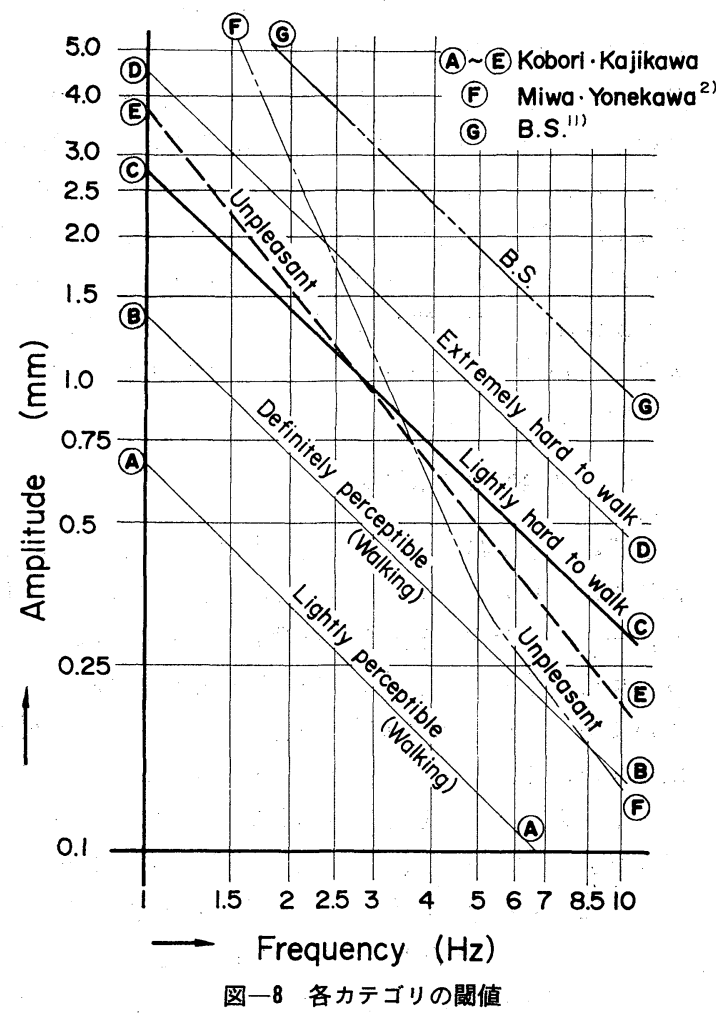

度を採用するのが適切であることがわかったので, 振動 速度と各カテゴリの評定率 (各振動に対し, 感じがその カテゴリに属していると答えた百分率）との関係を求め ると図一7 のようになる。そこで, 計量心理学上の閾值 の定義（反応が起きる確率が 50\% の刺激值）により， 各カテゴリの閾值を求めると表一 4 に示す值となる。こ れらの闘值を図一8 の実線（(A)〜D) で示した。なお， 図一8には弛緩した立位に扝ける不快の閾値 ${ }^{3)}$ (RMS 值) を(に, 三輪らの求めた緊張した立位における不快の閾 值 ${ }^{2)}$ (RMS 值) を( $\mathrm{E} に$, British Standards (B.S.) の道 路橋振動制限值 ${ }^{1 i}$ ) (20トン車の通過に伴う最大振動速度 $\sqrt{5}$ inch/sec) を(に示しておいた。

以上，橋梁振動が歩行者に及ぼす心理的影響を評価す るために必要なさまざまな心理実験とその結果について 述べてきた。

\section{5. 橋梁振動の評価法}

各節で述べてきたよらに橋梁の振動によって人間が受 ける影響は多様である。しかし, 生理的影響は通常の橋 梁振動においては小さく, それほど問題にならないであ ろう。また, 歩行位において人体には共振現象が認めら れないことや高い振動数範囲においては振動がそれほど
上体に伝達されないことなどから，人体の動的応答はそ れほど問題でないといえる。それに，心理的反応の実験 結果にはそれらがすでに加味されていると考えてよいで あろう。したがって, 橋梁の振動が人間に及ぼす影響は 現在のところでは心理的な反応のみを考慮すれば十分で あろう。そこで, 4. で得られた心理評価尺度によって 橋梁振動を評価する方法について考えてみた。

\section{（1）振動の刺激}

橋梁上で立ち止まることは比較的少ないために, 歩行 者の歩行位における振動感覚を対象に考えるならば, 振 動の刺激として振動速度を考えるのが妥当であろう。そ こで, 実際の記録から振動刺激としての振動速度を求め る方法を考えてみた。

スペクトル解析などのデータ処理の手法により波形に 含まれる周波数 $\left(f_{i}\right)$ とそれに対応する実効值 $\left(\sigma_{i}\right)$ が 求められている場合には, それぞれの速度成分の実効值 を考えればよいことから，次のようにして振動の刺激 (S) を求めればよい。

a) 波形が変位記録である場合

$$
S=\left\{\sum_{i=1}^{M}\left(\sigma_{d i} \cdot 2 \pi f_{i}\right)^{2}\right\}^{1 / 2}
$$

b）波形が速度記録である場合

$$
S=\left\{\sum_{i=1}^{M} \sigma_{v i}{ }^{2}\right\}^{1 / 2}
$$

c）波形が加速度記録である場合

$$
S=\left\{\sum_{i=1}^{M}\left(\sigma_{a i} / 2 \pi f_{i}\right)^{2}\right\}^{1 / 2}
$$

ここに, $\sigma_{d i}:$ 変位の実効値 $(\mathrm{cm})$

$\sigma_{v i}:$ 速度の実効值 $(\mathrm{cm} / \mathrm{sec})$

$\sigma_{a i}:$ 加速度の実効值 $\left(\mathrm{cm} / \mathrm{sec}^{2}\right)$

\section{$M:$ 周波数成分の個数}

スペクトル解析などにより周波数分析ができないとき は振動を速度計で測定し実効值を求めるのがよい。

また, 実効值が求められないが周波数成分が 1 つだけ であることが確かめられている場合には, 波形の最大振 幅の $1 / 3$ を実効值と考えれば一応の近似を与えるであろ $5^{12)}$ 。

\section{（2）振動の大きさ}

振動の刺激を求めることができたので心理的な振動の 大きさ $(V G)$ を求める。この $V G$ は式 (6) で示される が, 式 (6) を用いるためには振動の大きさのレベル $(V G L)$ と定数 $B$ を求めねばならない。そこで, 本研究 においては騒音評価に使う「Phon」「Sone」や三輪ら の提案する $\Gamma V G L 」\ulcorner V G 」$ と同様に，刺激と感覚の大 きさとの関倸において, 2 本の近似線が交わる点で $V G L$ が $40 \mathrm{~dB}$ となり，しかも $V G$ が 1.0 になるようにし 
表一5 振動の大きさ換算表

\begin{tabular}{|c|c|c|c|}
\hline Category & Stimulus & $V G L$ & $V G$ \\
\hline \multirow{8}{*}{ Lightly perceptible } & 0.45 & 30.2 & 0.32 \\
\hline & 0.50 & 31.1 & 0.36 \\
\hline & 0.55 & 31.9 & 0.39 \\
\hline & 0.60 & 32.6 & 0.43 \\
\hline & 0.65 & 33.3 & 0.46 \\
\hline & 0.70 & 34.0 & 0.50 \\
\hline & 0.75 & 34.6 & 0.54 \\
\hline & 0.80 & 35.1 & 0.57 \\
\hline \multirow{17}{*}{ Definitely perceptible } & 0.85 & 35.7 & 0.61 \\
\hline & 0.90 & 36.2 & 0.64 \\
\hline & 0.95 & 36.6 & 0.68 \\
\hline & 1.00 & 37.1 & 0.71 \\
\hline & 1.05 & 37.5 & 0.75 \\
\hline & 1.10 & 37.9 & 0.79 \\
\hline & 1.15 & $38: 3$ & 0.82 \\
\hline & 1.20 & 38.7 & 0.86 \\
\hline & 1.25 & 39.0 & 0.89 \\
\hline & 1.30 & 39.4 & 0.93 \\
\hline & 1.35 & 39.7 & 0.96 \\
\hline & 1.40 & 40.0 & 1.00 \\
\hline & 1.45 & 40.3 & 1.02 \\
\hline & 1.50 & 40.6 & 1.04 \\
\hline & 1.55 & 40.9 & 1.06 \\
\hline & 1.60 & 41.2 & 1.08 \\
\hline & 1.65 & 41.4 & 1.10 \\
\hline \multirow{13}{*}{ Lightly hard to walk } & 1.70 & 41.7 & 1.12 \\
\hline & 1.75 & 41.9 & 1.14 \\
\hline & 1.80 & 42.2 & 1.16 \\
\hline & 1.85 & 42.4 & 1.18 \\
\hline & 1.90 & 42.7 & 1.20 \\
\hline & 1.95 & 42.9 & 1.22 \\
\hline & 2.0 & 43.1 & 1.24 \\
\hline & 2.1 & 43.5 & 1.28 \\
\hline & 2.2 & 43.9 & 1.31 \\
\hline & 2.3 & 44.3 & 1.35 \\
\hline & 2.4 & 44.7 & 1.38 \\
\hline & 2.5 & 45.0 & 1.42 \\
\hline & 2.6 & 45.4 & 1.45 \\
\hline \multirow{14}{*}{ Extremely hard to walk } & 2.7 & 45.7 & 1.48 \\
\hline & 2.8 & 46.0 & 1.52 \\
\hline & 2.9 & 46.3 & 1.55 \\
\hline & 3.0 & 46.6 & 1.58 \\
\hline & 3.2 & 47.2 & 1.64 \\
\hline & 3.4 & 47.7 & 1.70 \\
\hline & 3.6 & 48.2 & 1.76 \\
\hline & 3.8 & 48.7 & 1.82 \\
\hline & 4.0 & 49.1 & 1.88 \\
\hline & 4.2 & 49.5 & 1.93 \\
\hline & 4.4 & 49.9 & 1.99 \\
\hline & 4.6 & 50.3 & 2.04 \\
\hline & 4.8 & 50.7 & 2.10 \\
\hline & 5.0 & 51.1 & 2.15 \\
\hline
\end{tabular}

た。すなわち，振動の大きさのレベル（VGL）は

$V G L=20 \log _{10}\left(S / S_{0}\right)$

ここに, $S_{0}=1.4 \times 10^{-2} \mathrm{~cm} / \mathrm{sec}$

となり，振動の大きさ $(V G)$ は, $V G L \leqq 40 \mathrm{~dB}$ で

$$
\log _{10} V G=0.05(V G L-40)
$$

$V G L>40 \mathrm{~dB}$ で

$$
\log _{10} V G=0.03(V G L-40)
$$

となる。式 (12)，(13)，(14) で示される振動の刺激 $S$ (歩 行位では振動速度) と振動の大きさの レベル(VGL), 振 動の大きさ (VG) を換算表としたものが 表一5 である。 この $V G$ を比較することにより橋梁の振動を心理的な 大きさによって判断することができる。すなわち，橋梁 の振動が人間に及ぼす心理的な影響を調べるためには従 来のよ5な実験あるいは計算によって動的応答を求め, その振動速度の実効值を算出し, 表一5によって振動の 大きさ $(V G)$ を求めれば, $V G$ が心理的大きさを表わ していることになる。

\section{（3）橋梁振動の恕限度}

さて, 橋梁においてどの程度の大きさの振動まで許さ れるか，を考えてみる。橋梁にはさまざまな用途があ り，一様にこの種の振動制限を設けるべきではなかろ ら。歩行者専用の歩道橋では特に厳しくしなければなら ないであろうし，自動車専用の道路橋ではこの種の制限 は必要ないであろう。そこで，歩行者の通る道路橋に おける一応の目安として, 通常頻繁に生ずるような振 動注1)によって歩きにくくないようにすべきである。そ のためには振動速度の実効値を $1.7 \mathrm{~cm} / \mathrm{sec}$ (図一8 の(C), $V G$ 值で 1.12) 未満とするのが望ましい。この值以下 にすれば図一8 の@と®が近接していることから歩行者 が立ち止まったとしても不快さはほとんど感じないであ ろ5。そして, この恕限度は B.S. $\left.{ }^{11}\right)$ の振動制限注2)に近 い值であり（4）で述べるよらに比較的容易に達成でき る値と思われる。

\section{（4）実在道路橋の振動評価}

以上, 述べてきた評価法によって実在道路橋の振 動3),12)を心理的大きさから評価してみた。図一9には実 在道路橋の支間長と振動の大きさ $(V G)$ とを橋梁形式 をパラメーターにして示した。ここで示した振動は空車 重量が約 10 トンと考えられる大型バスあるいは大型ダ ンプカーによってひき起こされたものである。図中， $V G$ が 1.12 の破線は本研究において提案する道路橋の 振動恕限度である。図示したように 10 トン車通過時に はこの制限を越える橋梁はないが，20 トン車通過時に は越えることが予想される。また，VG が大きい橋梁形 式にはランガー桁橋が目立ち, 今後, この種の橋梁は設 計において補剛桁の高さや吊材の配置などに十分な配慮

注 1）通常頻繁に生ずる振動とは，車両などの載荷確率および それらによる動的応答計算によらねばならないが，道路 橋では 20 トン車 1 台の車両通過に伴う振動程度と考え られる。

注 2） BS の振動制限は「20トン車の通過に伴い生ずる振動最 大速度を $\sqrt{5}$ inch/sec 以下にするのが 望をしい」とし ている。最大值であるため実効值をその $1 / 3$ とする ${ }^{12)}$ と,この制限はほぼ $1.86 \mathrm{~cm} / \mathrm{sec}$ 程度と考えられる。 


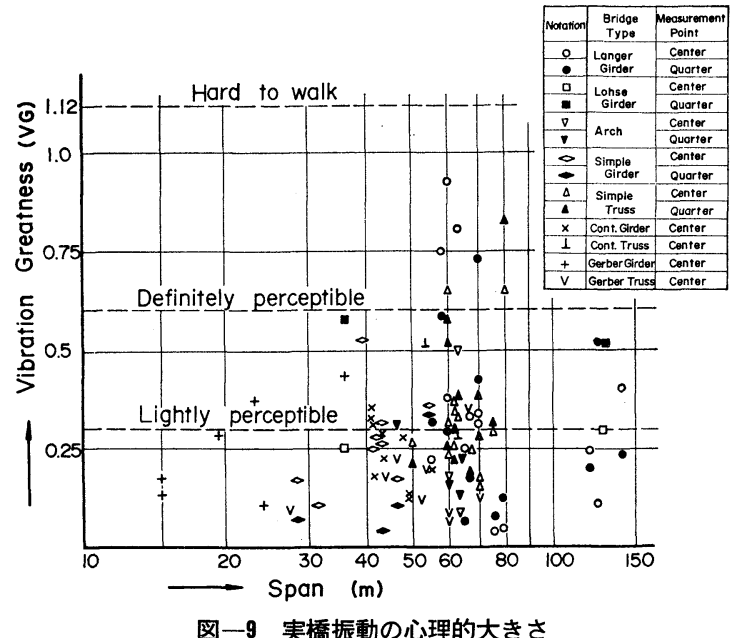

をし, 振動をできるだけ小さくする努力が要求される。

\section{6. むすび}

本研究は, 従来の橋梁設計において全く考慮されてい ない橋梁の振動が歩行者に与える影響について検討した ものである。その影響の中でも特に大きいと考えられる 心理的な反応については, 従来と異なった心理学的手法 を用いて同様な評価尺度を求め, 従来どおり振動量を測 定すれば心理的大きさが計算できることを示すとともに 道路橋の振動恕限度を提案した。

この研究では 1 10 Hz の上下振動を対象に行ったも ので，今後，長大支間の橋梁において問題になるであろ う低い振動数の振動や横方向の振動に対する検討も加え れば，さらに興味ある結果が得られると思う。
終りに，本稿をまとめるに当り，助言をいただいた金 沢大学医学部公衆衛生学教室 岡田 晃教授に深謝の意を 表わします。また, 本研究の実験についても協力いただ いた金沢大学の城戸隆良技官と同橋梁工学研究室の学生 諸氏に感謝いたします。なお, 本研究の一部に文部省科 学研究費の援助を受けたことを付記する。

\section{参 考 文 献}

1) Wright, R.N. and Walker, W.H. : Vibration and Deflection of Steel Bridges, A.I.S.C. Engineering Journal, 1972

2) 三輪・米川: 振動の評価法 $1,2,3$, 日本音響学会誌 27 巻 1 号, 1971

3）小堀・梶川：道路橋の振動とその振動感覚, 土木学会論 文報告集第 222 号, 1974

4) Goldman, D.E. and von Gierke, H.E. : Effects of shock and vibration on man, In shock and vibration Handbook, Edited by Harris, C.M. and Grede, C.E. (Vol. III), McGraw Hill, 1961

5) Roth, E.M. and Chambers, A.N. 著, 佐々木・山崎訳: 人間一環境系人間機能ハンドブックーVI章 振動, 人間と 技術社, 1972

6) 岡田 : 全身振動による影響・障害, 労働科学 41 巻 1 号, 1965

7）岡田・中村 : 騒音・振動・衝撃の影響と対策, 人間と技 術社, 1970

8）岡田：振動の生体に及ぼす影響 第 3 編, 北方産業衛生第 17 号, 1958

9）中谷: 尺度構成法, 講座心理学 2 計量心理学第 5 章, 東 京大学出版会, 1969

10）守田：騒音と騒音防止，オ一ム社， 1961

11) British Standards Institution : Composite Construction in Structural Steel and Concrete Part 2 Beams for Bridges C P 117, Appendex A, 1967

12）小堀・梶川：道路橋の振動調査について, 土木学会中部 支部研究発表会, 1974

(1974.2.28 - 受付) 